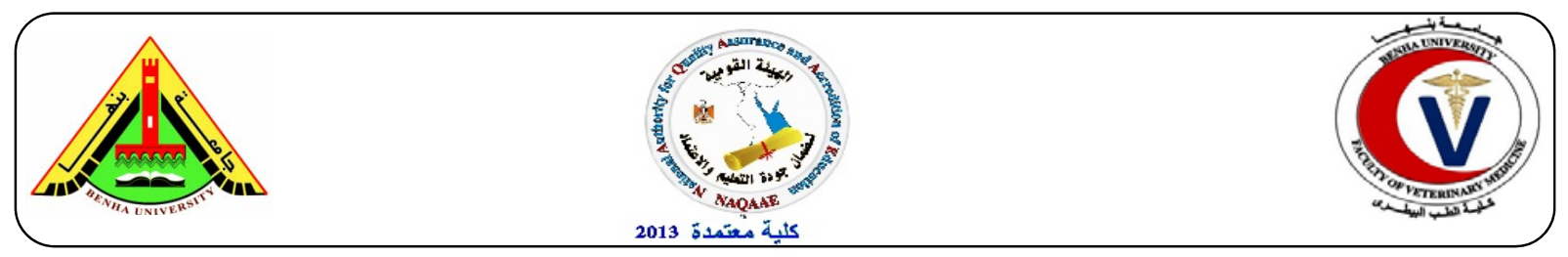

\title{
Effect of pomegranate peel methanolic extract on oxidative/antioxidant status of chilled diluted rabbit semen
}

\author{
Islam El-Sayed El-Seadawy ${ }^{1}$, Samy Ali Hussein Aziza², Yakout Abdelfattah El-Senosy², Walid \\ Said El-Nattat ${ }^{1 *}$, Magda Mohamed El-Tohamy ${ }^{1}$, Ahmed Saied Hussein ${ }^{3}$ \\ ${ }^{1}$ Animal Reproduction and AI Dept., Veterinary Research Division, National Research Centre, Egypt. \\ ${ }^{2}$ Biochemistry and Clinical Biochemistry Dept., Faculty of Veterinary Medicine, Benha University, Egypt. \\ ${ }^{3}$ Food Technology Dept, Food Industry and Nutrition Research Division, National Research Center, Egypt. \\ *Corresponding author: elnattat@gmail.com
}

\begin{abstract}
A B S T R A C T
The present study aimed to assess the lipid peroxidation and antioxidant enzymes activities of diluted rabbit semen enriched with different concentrations of pomegranate peel methanolic extract (PPME) during chilled storage. Semen was collected from 10 rabbit bucks, pooled, then divided into five aliquots and diluted each in $5 \mathrm{ml}$ Tris-citric acidglucose-egg yolk extender (TCGY). The 1st aliquot served as control, while PPME was added in different concentrations $(1.6,2.0,2.4$ and $2.8 \mathrm{mg} / 5 \mathrm{ml}$ TCGY extender) to the aliquots 2, 3, 4 and 5, respectively. Diluted semen samples were refrigerated at $5^{\circ} \mathrm{C}$ for 72 hours. Lipid peroxidation (MDA), $\mathrm{H}_{2} \mathrm{O}_{2}$ concentration, SOD, CAT activities and GSH concentration were evaluated in chilled seminal plasma during the chilling period. Obtained results clearly demonstrated that the addition of $1.6-2.8 \mathrm{mg}$ PPME in the chilled seminal plasma proved to be beneficial for minimizing MDA and $\mathrm{H}_{2} \mathrm{O}_{2}$ concentrations; in addition, they increased SOD, CAT activities and GSH concentration compared to the control. While, the concentrations of 2.4 and $2.8 \mathrm{mg}$ were the best PPME enrichments that maintained the highest SOD, CAT activities and GSH concentration. It was concluded that the enrichment of rabbit semen TCGY extender with $2.4-2.8$ mg PPME during chilling had significantly decreased sperm lipid peroxidation and $\mathrm{H}_{2} \mathrm{O}_{2}$ production beside they enhanced the activities of antioxidant enzymes and the reduced glutathione.
\end{abstract}

Key words: Male rabbits, Semen extender, pomegranate peel extract, Antioxidants.

(http://www.bvmj.bu.edu.eg)

(BVMJ-33(2): 1-8, DECEMBER, 2017)

\section{INTRODUCTION}

Concerning the progressive increasing in the global demand for rabbit meat, commercial rabbit breeding becomes more dependent on artificial insemination (AI) rather than traditional natural mating (Rosato and Iaffaldano 2011). Therefore, developing and improving methods for semen preservation would provide adequate fertility rates that maintain the high production rates for rabbit industry. Several studies on preservation protocols and extender composition have been carried out (Rosato and Iaffaldano 2011; Di Iorio et al., 2014 and Johinke et al., 2014). Unfortunately, the ability of rabbit sperm to survive in vitro after chilled (Iaffaldano et al., 2010) or frozen storage (Moce' and Vicente, 2009) is limited. This is in part due to lipid peroxidation caused by a supra-physiological level of reactive oxygen species (ROS), which affects sperm membrane lipids, proteins, nucleic acids and sugars (Kim et al., 2011). The majority of ROS are continuously neutralized by antioxidants contained in rabbit semen itself (Mourvaki et al., 2010), while the endogenous antioxidants are insufficient to counteract the lipid peroxidation that occurs during sperm storage (Castellini et al., 2000). Several attempts have been made with dietary supra-nutritional antioxidants supplementation aimed to enhance rabbit sperm quality (Yousef et al., 2003) or its survival during refrigeration (Castellini et al., 2000). However, reports evaluating the efficacy of the addition of natural antioxidants in the rabbit seminal extenders were lacking. Natural extracts and infusions from fruits and vegetables were used in semen extenders for preserving animal's sperms (El-Sheshtawy et al., 2016; El-Nattat et al., 2016). Plants and their products are potential sources of phytochemicals that have been found to counteract free radicals due to their antioxidant activity (Khalafalla et al., 2010). Pomegranate plant (Punica granatum L.) is a shrub and its fruit is a rich source of bioactive 
phytochemicals such as tannins and other phenolics. Pomegranate peel extracts were reported to possess remarkable antioxidant, antibacterial, anti-inflammatory and hypolipidemic bioactivities (Panichayupakaranant et al., 2010). These potential health benefits are attributed to the polyphenolic compounds that the pomegranate peel extracts contained punicalagin A, punicalagin B, gallic acid, ellagic acid, chlorogenic acid, caffeic acid, catechin, epicatechin, rutin, quercetin, and galangal (Qu et al., 2012).

Hence, the present study was designed to assess the effect of PPME, supplementation to a basic rabbit semen extender, on lipid peroxidation, $\mathrm{H}_{2} \mathrm{O}_{2}$ concentration, some antioxidant enzymes activities and reduced glutathione concentration in chilled rabbit semen over 72 hours.

\section{MATERIAL AND METHODS}

\subsection{Collection of Pomegranate peel samples:}

Pomegranate fruits were collected in October, 2015 from El-Behira governorate, Egypt. The peel of Pomegranate was manually removed and dried in an air-oven at $50{ }^{\circ} \mathrm{C}$ for $16 \mathrm{~h}$. The dried sample was ground and passed through a 40-mesh sieve and packed in polyethylene bags and stored at -20 ${ }^{\circ} \mathrm{C}$ until use

\subsection{Preparation of extract:}

PPME was prepared by mixing 30 grams of raw material with $300 \mathrm{~mL}$ methanol $(1: 10 \mathrm{w} / \mathrm{v})$ and stirred at room temperature. The solution was kept at $4{ }^{\circ} \mathrm{C}$ for $24 \mathrm{~h}$. The extract obtained was filtered, then dried using rotary evaporator under reduced pressure at $40{ }^{\circ} \mathrm{C}$ and the final yield of extract was recorded (Roopalatha and Nair, 2013). The extract was reconstituted in $10 \mathrm{~mL}$ DMSO and stored at $80{ }^{\circ} \mathrm{C}$ till further use.

\subsection{Animals management and semen collection:}

2.3.1. Ten sexually mature and fertile New Zealand White (NZW) male rabbits were obtained from the same herd in a commercial farm, for the purpose of this study. Rabbits aged 26-30 weeks and 2.3-2.9 $\mathrm{kg}$ initial weight.

2.3.2. Rabbit Bucks were trained to mount teaser female and then ejaculated in artificial vagina (IMV, France) adapted at $40-42{ }^{\circ} \mathrm{C}$. Semen was collected twice weekly. Each ejaculate was assessed for initial semen quality; only those that were white, $>200 \mu \mathrm{L}$ in volume, $\geq 300 \times 10^{6}$ cells $/ \mathrm{mL}$ in concentration and with $\geq 70 \%$ motile spermatozoa were included in the study.

\subsubsection{Experimental design:}

Immediately after semen collection, selected ejaculates were pooled so as to allow sufficient volume for each treatment. The pooled sample was splitted in five subsamples (each of $500 \mu \mathrm{L}$ ) to prepare one of the five treatments as follows:

1. The first aliquot was diluted 1:10 in TCGY basic extender and served as control.

2. The other four aliquots were diluted $1: 10$ in the TCGY extender enriched with 1.6, 2.0, 2.4 and $2.8 \mathrm{mg}$ PPME/5ml TCGY basic extender.

\subsection{Assessment of oxidative/antioxidants status:}

The diluted semen samples were refrigerated in an incubator at $4{ }^{\circ} \mathrm{C}$ for $72 \mathrm{~h}$. Oxidative/antioxidant status will be measured in diluted semen during chilling periods (2, 24, 48 and 72 hours post chilling) using commercially kits obtained from Bio Diagnostic Research office (Dokki, Giza, Egypt).

2.4.1. Determination of Lipid peroxidation ( $\mathrm{nmol} / \mathrm{ml})$ :

Thiobarbituric acid-reactive substances (TBARS) were determined according to the method of Ohkawa, et al., (1979).

2.4.2. Determination of Hydrogen peroxide $(\mathrm{mM} / \mathrm{L})$ :

The $\mathrm{H}_{2} \mathrm{O}_{2}$ level was determined according to the method of Aebi, (1984).

2.4.3. Determination of Superoxide Dismutase (SOD) activity $(\mathrm{U} / \mathrm{ml})$ :

The activity of SOD was determined according to Nishikimi et al., (1972).

2.4.4. Determination of Catalase activity (U/L):

In The activity of catalase was determined according to Aebi, (1984).

2.4.5. Determination of Reduced glutathione $(\mathrm{mg} / \mathrm{dl})$ :

Reduced glutathione concentration was assayed according to Beutler et al., (1963).

\subsection{Statistical analysis:}

Statistical analysis was analyzed using the SAS computerized program v. 9.2 (SAS, 2008) to calculate the analysis of variance (ANOVA) for the different parameters between control and additives replications. Significant difference between means was calculated using Duncan multiple range test at $P<0.05$.

\section{RESULTS}

\subsection{Biochemical analysis of tris extender diluted semen enriched with PPME:}

\subsubsection{MDA concentration $(\mathrm{nmol} / \mathrm{ml})$ :}


Table (1): MDA concentrations (Mean $\pm \mathrm{SE}, \mathrm{nmol} / \mathrm{ml}$ ) of diluted rabbit buck semen in TCG extender enriched with different concentrations ( $\mathrm{mg} / 5 \mathrm{ml}$ extender) of PPME after chilled storage.

\begin{tabular}{|c|c|c|c|c|c|c|c|c|}
\hline \multirow{2}{*}{$\begin{array}{l}\text { Chilling } \\
\text { Duration } \\
\text { (hours) }\end{array}$} & \multirow[b]{2}{*}{ Control (TCGY) } & \multicolumn{4}{|c|}{ Concentrations of PPME $(\mathrm{mg}) /$ tris-extender $(5 \mathrm{ml})$} & \multirow[b]{2}{*}{$P<$} & \multirow{2}{*}{$\begin{array}{l}\text { Overall } \\
\text { mean* }\end{array}$} & \multirow[b]{2}{*}{$P<$} \\
\hline & & 1.6 & 2.0 & 2.4 & 2.8 & & & \\
\hline 2 & $2.69^{\mathrm{Ab}} \pm 0.19$ & $2.71^{\mathrm{Aa}} \pm 0.20$ & $2.26^{\mathrm{Ab}} \pm 0.17$ & $2.16^{\mathrm{Aa}} \pm 0.05$ & $2.14^{\mathrm{Aa}} \pm 0.17$ & 0.0773 & $2.32^{\mathrm{k} 1}$ & \multirow{4}{*}{0.0457} \\
\hline 24 & $2.77^{\mathrm{ABb}} \pm 0.17$ & $2.72^{\mathrm{ABa}} \pm 0.21$ & $3.11^{\mathrm{Aa}} \pm 0.06$ & $2.12^{\mathrm{Ca}} \pm 0.15$ & $2.42^{\mathrm{BCa}} \pm 0.22$ & 0.0207 & $2.59^{\mathrm{k}}$ & \\
\hline 48 & $3.28^{\mathrm{Ab}} \pm 0.30$ & $2.93^{\mathrm{ABa}} \pm 0.16$ & $2.43^{\mathrm{Bb}} \pm 0.20$ & $2.40^{\mathrm{Ba}} \pm 0.19$ & $2.30^{\mathrm{Ba}} \pm 0.21$ & 0.0430 & $2.52^{\mathrm{k} 1}$ & \\
\hline 72 & $4.16^{\mathrm{Aa}} \pm 0.31$ & $2.14^{\mathrm{Ba}} \pm 0.17$ & $2.55^{\mathrm{Bb}} \pm 0.18$ & $2.06^{\mathrm{Ba}} \pm 0.17$ & $2.23^{\mathrm{Ba}} \pm 0.31$ & 0.0006 & $2.25^{1}$ & \\
\hline$P<$ & 0.0125 & 0.0819 & 0.0305 & 0.4584 & 0.8546 & \multirow{3}{*}{\multicolumn{3}{|c|}{$\begin{array}{l}\text { Interaction: time } * \text { concentration }= \\
0.1299\end{array}$}} \\
\hline $\begin{array}{l}\text { Overall } \\
\text { mean* }\end{array}$ & & $2.63^{\mathrm{K}}$ & $2.58^{\mathrm{K}}$ & $2.18^{\mathrm{L}}$ & $2.27^{\mathrm{L}}$ & & & \\
\hline$P<$ & \multicolumn{5}{|c|}{0.0034} & & & \\
\hline
\end{tabular}

Overall mean concern the 2 way analysis without the control.

Different superscripts (A, B, C, D, E) within the same row indicate significant difference using Duncan's multiple range test $(P<0.05)$.

Different superscripts (a, b, c, d, e) within the same column indicate significant difference using Duncan's multiple range test $(P<0.05)$.

Different superscripts $(\mathrm{K}, \mathrm{L}, \mathrm{M}, \mathrm{N})$ of overall means within rows indicate significant difference using Duncan's multiple range test $(P<0.05)$.

Different superscripts $(\mathrm{k}, 1, \mathrm{~m}, \mathrm{n})$ of overall means within columns indicate significant difference using Duncan's multiple range test $(P<0.05)$.

Table (2): $\mathrm{H}_{2} \mathrm{O}_{2}$ concentrations (Mean $\pm \mathrm{SE}, \mathrm{mmol} / \mathrm{l}$ ) of diluted rabbit buck semen in TCG extender enriched with different concentrations (mg/5 ml extender) of PPME after chilled storage.

\begin{tabular}{|c|c|c|c|c|c|c|c|c|}
\hline \multirow{2}{*}{$\begin{array}{l}\text { Chilling } \\
\text { Duration } \\
\text { (hours) }\end{array}$} & \multirow{2}{*}{$\begin{array}{l}\text { Control } \\
(\mathrm{TCGY})\end{array}$} & \multicolumn{4}{|c|}{ Concentrations of PPME (mg) / tris-extender $(5 \mathrm{ml})$} & \multirow[b]{2}{*}{$P<$} & \multirow{2}{*}{$\begin{array}{l}\text { Overall } \\
\text { mean* }\end{array}$} & \multirow[b]{2}{*}{$P<$} \\
\hline & & 1.6 & 2.0 & 2.4 & 2.8 & & & \\
\hline 2 & $0.10^{\mathrm{Bb}} \pm 0.003$ & $0.11^{\mathrm{Ba}} \pm 0.006$ & $0.09^{\mathrm{BCb}} \pm 0.008$ & $0.07^{\mathrm{Cb}} \pm 0.01$ & $0.14^{\mathrm{Aa}} \pm 0.01$ & 0.0028 & $0.103^{\mathrm{k}}$ & \multirow{4}{*}{0.0170} \\
\hline 24 & $0.11^{\mathrm{Ab}} \pm 0.008$ & $0.07^{\mathrm{Bb}} \pm 0.01$ & $0.13^{\mathrm{Aa}} \pm 0.009$ & $0.11^{\mathrm{Aa}} \pm 0.002$ & $0.07^{\mathrm{Bb}} \pm 0.01$ & 0.0069 & $0.094^{\mathrm{k} 1}$ & \\
\hline 48 & $0.12^{\mathrm{Aab}} \pm 0.006$ & $0.11^{\mathrm{ABa}} \pm 0.006$ & $0.09^{\mathrm{BCb}} \pm 0.003$ & $0.06^{\mathrm{Db}} \pm 0.01$ & $0.08^{\mathrm{Cb}} \pm 0.004$ & 0.0008 & $0.085^{1}$ & \\
\hline 72 & $0.14^{\mathrm{Aa}} \pm 0.009$ & $0.09^{\mathrm{BCb}} \pm 0.005$ & $0.07^{\mathrm{CDc}} \pm 0.007$ & $0.06^{\mathrm{Db}} \pm 0.01$ & $0.12^{\mathrm{Ba}} \pm 0.01$ & 0.0003 & $0.083^{1}$ & \\
\hline$P<$ & 0.0262 & 0.0449 & 0.0046 & 0.0145 & 0.0043 & \multirow{3}{*}{\multicolumn{3}{|c|}{$\begin{array}{l}\text { Interaction: time*concentration } \\
\qquad=0.0001\end{array}$}} \\
\hline $\begin{array}{l}\text { Overall } \\
\text { mean* }\end{array}$ & & $0.093^{\mathrm{K}}$ & $0.095^{\mathrm{K}}$ & $0.075^{\mathrm{L}}$ & $0.102^{\mathrm{K}}$ & & & \\
\hline$P<$ & \multicolumn{5}{|c|}{0.0014} & & & \\
\hline
\end{tabular}


El-Seadawy et al. (2017). BVMJ-33(2): 1-8

Table (3): SOD activity (Mean $\pm \mathrm{SE}, \mathrm{U} / \mathrm{ml}$ ) of diluted rabbit buck semen in TCG extender enriched with different concentrations (mg/5 ml extender) of PPME after chilled storage.

\begin{tabular}{|c|c|c|c|c|c|c|c|c|}
\hline \multirow{2}{*}{$\begin{array}{l}\text { Chilling } \\
\text { Duration } \\
\text { (hours) }\end{array}$} & \multirow{2}{*}{$\begin{array}{l}\text { Control } \\
(\mathrm{TCGY})\end{array}$} & \multicolumn{4}{|c|}{ Concentrations of PPME (mg) / tris-extender $(5 \mathrm{ml})$} & \multirow[b]{2}{*}{$P<$} & \multirow{2}{*}{$\begin{array}{l}\text { Overall } \\
\text { mean* }\end{array}$} & \multirow{2}{*}{$P<$} \\
\hline & & 1.6 & 2.0 & 2.4 & 2.8 & & & \\
\hline 2 & $87.03^{\mathrm{Ab}} \pm 1.48$ & $55.51^{\mathrm{Cab}} \pm 8.81$ & $36.80^{\mathrm{Dc}} \pm 4.30$ & $77.68^{\mathrm{ABa}} \pm 6.47$ & $63.92^{\mathrm{BCb}} \pm 2.82$ & 0.0006 & $58.47^{1}$ & \multirow{4}{*}{0.0023} \\
\hline 24 & $95.41^{\mathrm{Ab}} \pm 0.47$ & $59.46^{\mathrm{Bab}} \pm 6.18$ & $51.67^{\mathrm{Bbc}} \pm 4.40$ & $61.62^{\mathrm{Ba}} \pm 4.62$ & $90.85^{\mathrm{Aa}} \pm 5.51$ & 0.0001 & $65.90^{1}$ & \\
\hline 48 & $97.54^{\mathrm{Ab}} \pm 0.58$ & $70.11^{\mathrm{Ba}} \pm 5.61$ & $56.31^{\mathrm{Bb}} \pm 7.31$ & $62.27^{\mathrm{Ba}} \pm 6.15$ & $79.13^{\mathrm{Bb}} \pm 6.56$ & 0.0046 & $65.45^{1}$ & \\
\hline 72 & $113.94^{\mathrm{Aa}} \pm 6.38$ & $44.86^{\mathrm{Cb}} \pm 3.11$ & $85.00^{\mathrm{Ba}} \pm 2.88$ & $80.67^{\mathrm{Ba}} \pm 6.07$ & $90.20^{\mathrm{Ba}} \pm 5.11$ & 0.0001 & $75.18^{\mathrm{k}}$ & \\
\hline$P<$ & 0.0027 & 0.1107 & 0.0009 & 0.1008 & 0.0153 & \multirow{3}{*}{\multicolumn{3}{|c|}{$\begin{array}{l}\text { Interaction: time*concentration } \\
\qquad=0.0001\end{array}$}} \\
\hline $\begin{array}{l}\text { Overall } \\
\text { mean* }\end{array}$ & & $57.48^{\mathrm{M}}$ & $57.44^{\mathrm{M}}$ & $70.56^{\mathrm{L}}$ & $79.52^{\mathrm{K}}$ & & & \\
\hline$P<$ & \multicolumn{5}{|c|}{0.0001} & & & \\
\hline
\end{tabular}

Table (4): CAT activity (Mean \pm SE, U/L) of diluted rabbit buck semen in TCG extender enriched with different concentrations (mg/5 ml extender) of PPME after chilled storage.

\begin{tabular}{|c|c|c|c|c|c|c|c|c|}
\hline \multirow{2}{*}{$\begin{array}{l}\text { Chilling } \\
\text { Duration } \\
\text { (hours) }\end{array}$} & \multirow{2}{*}{$\begin{array}{l}\text { Control } \\
(\mathrm{TCGY})\end{array}$} & \multicolumn{4}{|c|}{ Concentrations of PPME (mg) / tris-extender $(5 \mathrm{ml})$} & \multirow[b]{2}{*}{$P<$} & \multirow{2}{*}{$\begin{array}{l}\text { Overall } \\
\text { mean* }\end{array}$} & \multirow[b]{2}{*}{$P<$} \\
\hline & & 1.6 & 2.0 & 2.4 & 2.8 & & & \\
\hline 2 & $99.64^{\mathrm{Dc}} \pm 2.27$ & $214.36^{\mathrm{Cb}} \pm 6.22$ & $253.73^{\mathrm{BCa}} \pm 20.22$ & $306.88^{\mathrm{Bb}} \pm 30.75$ & $466.7^{\mathrm{Aa}} \pm 17.28$ & 0.0001 & $310.42^{\mathrm{m}}$ & \multirow{4}{*}{0.0041} \\
\hline 24 & $150.04^{\mathrm{Cb}} \pm 11.14$ & $256.22^{\mathrm{Bab}} \pm 20.54$ & $278.88^{\mathrm{Ba}} \pm 17.14$ & $340.13^{\mathrm{Bb}} \pm 29.61$ & $463.73^{\mathrm{Aa}} \pm 44.01$ & 0.0001 & $334.74^{1 \mathrm{~m}}$ & \\
\hline 48 & $241.76^{\mathrm{Ca}} \pm 11.61$ & $283.84^{\mathrm{Ca}} \pm 12.75$ & $256.23^{\mathrm{Ca}} \pm 14.38$ & $366.97^{\mathrm{Bb}} \pm 11.82$ & $506.46^{\mathrm{Aa}} \pm 27.83$ & 0.0001 & $353.38^{\mathrm{k} 1}$ & \\
\hline 72 & $248.88^{\mathrm{Ca}} \pm 11.61$ & $297.62^{\mathrm{Ba}} \pm 18.53$ & $265.55^{\mathrm{BCa}} \pm 11.3$ & $459.07^{\mathrm{Aa}} \pm 12.32$ & $451.48^{\mathrm{Aa}} \pm 17.41$ & 0.0001 & $368.43^{\mathrm{k}}$ & \\
\hline$P<$ & 0.0001 & 0.0232 & 0.6927 & 0.0084 & 0.5853 & \multirow{3}{*}{\multicolumn{3}{|c|}{$\begin{array}{l}\text { Interaction: time*concentration } \\
\quad=0.0173\end{array}$}} \\
\hline $\begin{array}{l}\text { Overall } \\
\text { mean* }\end{array}$ & & $263.02^{\mathrm{M}}$ & $263.60^{M}$ & $368.27^{\mathrm{L}}$ & $472.10^{\mathrm{K}}$ & & & \\
\hline$P<$ & \multicolumn{5}{|c|}{0.0001} & & & \\
\hline
\end{tabular}


Table (5): GSH concentration (Mean \pm SE, $\mathrm{mg} / \mathrm{dl}$ ) of diluted rabbit buck semen in TCG extender enriched with different concentrations (mg/5 ml extender) of PPME after chilled storage.

\begin{tabular}{|c|c|c|c|c|c|c|c|c|}
\hline \multirow{2}{*}{$\begin{array}{l}\text { Chilling } \\
\text { Duration } \\
\text { (hours) }\end{array}$} & \multirow{2}{*}{$\begin{array}{l}\text { Control } \\
\text { (TCGY) }\end{array}$} & \multicolumn{4}{|c|}{ Concentrations of PPME $(\mathrm{mg}) /$ tris-extender $(5 \mathrm{ml})$} & \multirow[b]{2}{*}{$P<$} & \multirow{2}{*}{$\begin{array}{l}\text { Overall } \\
\text { mean* }\end{array}$} & \multirow[b]{2}{*}{$P<$} \\
\hline & & 1.6 & 2.0 & 2.4 & 2.8 & & & \\
\hline 2 & $4.91^{\mathrm{Aa}} \pm 0.36$ & $4.75^{\mathrm{Aa}} \pm 0.17$ & $3.86^{\mathrm{Aab}} \pm 0.16$ & $5.20^{\mathrm{Aa}} \pm 0.48$ & $4.62^{\mathrm{Aa}} \pm 0.49$ & 0.1980 & $4.61^{\mathrm{k}}$ & \multirow{4}{*}{0.0001} \\
\hline 24 & $4.35^{\mathrm{ABa}} \pm 0.55$ & $3.93^{\mathrm{ABab}} \pm 0.23$ & $3.35^{\mathrm{Bb}} \pm 0.08$ & $4.88^{\mathrm{Aa}} \pm 0.32$ & $4.55^{\mathrm{Aa}} \pm 0.05$ & 0.0424 & $4.18^{1}$ & \\
\hline 48 & $4.89^{\mathrm{ABa}} \pm 0.13$ & $3.80^{\mathrm{Cb}} \pm 0.41$ & $4.15^{\mathrm{BCa}} \pm 0.32$ & $4.44^{\mathrm{ABCa}} \pm 0.08$ & $5.17^{\mathrm{Aa}} \pm 0.15$ & 0.0225 & $4.39^{\mathrm{k} 1}$ & \\
\hline 72 & $1.92^{\mathrm{Cb}} \pm 0.09$ & $2.86^{\mathrm{Bc}} \pm 0.10$ & $2.51^{\mathrm{BCc}} \pm 0.21$ & $4.75^{\mathrm{Aa}} \pm 0.40$ & $4.02^{\mathrm{Aa}} \pm 0.21$ & 0.0001 & $3.54^{\mathrm{m}}$ & \\
\hline$P<$ & 0.0007 & 0.0062 & 0.0034 & 0.5448 & 0.1090 & \multirow{3}{*}{\multicolumn{3}{|c|}{$\begin{array}{l}\text { Interaction: time*concentration } \\
\qquad=0.0329\end{array}$}} \\
\hline $\begin{array}{l}\text { Overall } \\
\text { mean* }\end{array}$ & & $3.84^{\mathrm{L}}$ & $3.47^{\mathrm{L}}$ & $4.82^{\mathrm{K}}$ & $4.59^{\mathrm{K}}$ & & & \\
\hline$P<$ & \multicolumn{5}{|c|}{0.0001} & & & \\
\hline
\end{tabular}

Overall mean concern the 2 way analysis without the control.

Different superscripts (A, B, C, D, E) within the same row indicate significant difference using Duncan's multiple range test $(P<0.05)$.

Different superscripts ( $\mathrm{a}, \mathrm{b}, \mathrm{c}, \mathrm{d}, \mathrm{e})$ within the same column indicate significant difference using Duncan's multiple range test $(P<0.05)$.

Different superscripts $(\mathrm{K}, \mathrm{L}, \mathrm{M}, \mathrm{N})$ of overall means within rows indicate significant difference using Duncan's multiple range test $(P<0.05)$.

Different superscripts $(\mathrm{k}, 1, \mathrm{~m}, \mathrm{n})$ of overall means within columns indicate significant difference using Duncan's multiple range test $(P<0.05)$ 
Concerning the enrichments of $5 \mathrm{ml}$ tris extender with different concentrations of PPME (within rows) (Table 1), the concentrations of 1.6, 2.0, 2.4 and $2.8 \mathrm{mg}$ PPME / $5 \mathrm{ml}$ tris extender showed significant $(\mathrm{P}<0.0430, P<0.0006)$ decrease in MDA concentration after 48 and72 hours compared to the control ( $0 \mathrm{mg}$ PPME). The MDA concentration overall means of 2.4 and $2.8 \mathrm{mg} / 5$ $\mathrm{ml}$ were significantly $(P<0.0034)$ decreased compared to the treatments 1.6 and $2.0 \mathrm{mg} / 5 \mathrm{ml}$.

\subsection{2. $\mathrm{H}_{2} \mathrm{O}_{2}$ concentration ( $\left.\mathrm{mmol} / \mathrm{l}\right)$ :}

Concerning the enrichments of $5 \mathrm{ml}$ tris extender with different concentrations of PPME (within rows) (Table 2), the concentrations of $2.4 \mathrm{mg}$ PPME / $5 \mathrm{ml}$ tris extender were significantly $(P<0.0008, P<0.0003)$ the best PPME enrichments that maintained lower $\mathrm{H}_{2} \mathrm{O}_{2}$ concentration after 48 and 72 hours compared to the control ( 0 mg PPME) and the other concentrations. This was approved by the analogous overall means with its respective concentration $(P<0.0014)$.

\subsubsection{SOD activity $(\mathrm{U} / \mathrm{ml})$ :}

Concerning the enrichments of $5 \mathrm{ml}$ tris extender with different concentrations of MLME (within rows) (Table 3 ), the concentration of $2.8 \mathrm{mg}$ was the best PPME enrichments that maintained highest SOD activity compared to the concentrations of 1.6, 2.0 and $2.4 \mathrm{mg}$ PPME from 24 hours $(P<0.0001)$. This was analogous to overall means with its respective concentration $(P<0.0001)$.

\subsubsection{CAT activity (U/L):}

Concerning the enrichments of $5 \mathrm{ml}$ tris extender with different concentrations of PPME within rows (Table 4), the concentrations of 1.6, 2.0, 2.4 and 2.8 $\mathrm{mg}$ showed significant $(P<0.0001)$ increase in CAT activity from 2 to 72 hours compared to the control, while the concentration of $2.8 \mathrm{mg}$ is the best PPME enrichments that maintained the highest CAT activity. This was analogous to the CAT activity overall mean with its respective concentration $(P<0.0001)$.

\subsubsection{GSH concentration ( $\mathrm{mg} / \mathrm{dl})$ :}

Concerning the enrichments of $5 \mathrm{ml}$ tris extender with different concentrations of PPME (within rows) (Table 5), the concentrations of 1.6, 2.0, 2.4 and $2.8 \mathrm{mg}$ PPME / $5 \mathrm{ml}$ tris extender showed significant $(P<0.0001) \quad$ increase in GSH concentration compared to control after 72 hours, while the concentrations of 2.4 and $2.8 \mathrm{mg}$ were the best PPME enrichments that maintained the highest GSH concentration after 72 hours. This was analogous to the GSH concentration overall means with their respective concentrations $(P<0.0001)$.

\section{DISCUSSION}

A good semen quality is a main target requested for artificial insemination. This is in need for a physiological boundary of ROS to accomplish its role. Whereas, high levels of ROS is sticky related with the hindrance of sperm fertilizing capability (Capucho et al., 2012). The chilling is one of the detrimental factors that induce the production of ROS in extended semen of rabbits (Rosato and Iaffaldano, 2011). The feed on natural products as prescribed in folk medicine improved the motility and fertilizing capability of sperm, through facing up the ROS deteriorating effects, as they enclose in their folds polyphenolic compounds, minerals, vitamins, enzymes and other antioxidants that play a role in scavenging free radicals and up-regulate certain metal chelation reactions (Burdock 1998).

Pomegranate peel methanolic extract was used in this study as a natural enrichment to the basic semen extender owing to its antioxidant properties which mainly attributed to high contents of bioactive phytochemicals such as tannins and other phenolics (Ismail et al., 2010; Reddy et al., 2007). The present results (Table 1 - 5) showed that the addition of $1.6-2.8 \mathrm{mg}$ MLME/ $5 \mathrm{ml}$ Tris extender had significantly minimized sperm lipid peroxidation and $\mathrm{H}_{2} \mathrm{O}_{2}$ concentration and increased SOD, CAT activities and GSH concentration during chilling till 72 hours compared to the control treatment, while the concentrations of 2.4 and $2.8 \mathrm{mg}$ were the best PPME enrichments that maintained the highest SOD, CAT activities and GSH concentration. These results followed the same trend as the findings of Guo et al. (2008), Türk et al. (2008), Yüce and Aksakal (2007) and Amini Rad et al. (2009) who reported that oral consumption of pomegranate juice provides significant reduction in testicular tissue MDA level and significant increments in GSH level, GSH-Px, and CAT activities and also significantly improves sperm count, motility, and abnormal sperm rate in non stressed healthy laboratory animals.

The enhancement in semen quality observed in this study could in part be attributed to the presence of some phenolic compounds in PPME as pyrogallol, protochatechuic acid, gallic acid, $p$ coumaric acid, rosmarinic acid, catachine, rutin, naringeen, scoplatine, myrcetin and hisperdin that have antioxidant activities through reduction of oxidative stress, lipid peroxidation and free radical generation (Moretti et al., 2012; Abeed Al- 
Mashkor et al., 2014; Hmid et al., 2013; Reddy et al. 2007). This may interpret the benefit beyond the enrichment of rabbit semen tris-based extender with PPME through the synergism of phenolic compounds to overcome the lipid peroxidation process induced via chilling period (Moyo et al., 2012; Johinke et al., 2014; El-Sheshtawy et al. 2016; Al- Daraji, 2015). In conclusion, the enrichment of rabbit semen tris-basic extender with $2.4-2.8 \mathrm{mg}$ PPME / $5 \mathrm{ml}$ tris-extender (as the best and safe concentrations) minimize the sperm lipid peroxidation and $\mathrm{H}_{2} \mathrm{O}_{2}$ concentration, in addition to the elevation of SOD, CAT activities and GSH concentration.

\section{REFERENCES}

Abeed Al-Mashkor, I. M. 2014. Total phenol, Total Flavonoids and Antioxidant Activity of Pomegranate Peel. International Journal of ChemTech Research, 6: 4656-4661.

Aebi, H. 1984. Catalase in vitro. Methods Enzymol, 105: 121-126.

Al-Daraji H.J. 2015. The uses of pomegranate juice for counteract lipid peroxidation that naturally occurred during liquid storage of roosters' semen. Pharmacogn Commu; 5(1): 70-76.

Amini Rad O, Khalili MA and Soltani Gord Faramarzi HR. 2009. Influence of pomegranate juice on sperm parameters and fertility in mice (Article in Persian). Medical Journal of Hormozgan University, 13: 182188.

Beutler, E., Duron, O., and Kelly, M.B. 1963. lmproved method for the determination of blood glutathione. J. Lab. Clin. Med. 61, 882-888.

Burdock G.A. 1998. Review of the biological properties and toxicity of Bee propolis (propolis). Food Chem Toxicol;: 36: 347363.

Capucho C, Sette R, de Souza Predes F, de Castro Monteiro J, Pigoso AA, Barbieri R, Dolder MAH, Severi-Aguiar GDC. 2012. Green Brazilian propolis effects on sperm count and epididymis morphology and oxidative stress. Food Chem Toxicol; 50: 3956-3962.

Castellini, C., Lattaioli, P., Bernardini, M., Dal Bosco, A. 2000. Effect of dietary alphatocopheryl acetate and ascorbic acid on rabbit semen stored at 5 degrees $\mathrm{C}$. Theriogenology: 54, 523-533.

Di lorio, M., Manchisi A, Rocco M, Chrenek P, Iaffaldano N. 2014. Comparison of different extenders on the preservability of rabbit semen stored at $5^{\circ} \mathrm{C}$ for 72 hours. Ital $\mathrm{J}$ Anim Sci; 13:710-714.

El-Nattat WS, El-Sheshtawy RI, El-Batawy KA, Shahba MI, El-Seadawy IE. 2016. Preservability of buffalo bull semen in triscitrate extender enriched with bee's honey. J Innov Pharmaceut Biol Sci; 3(1): 180-185.

El-Sheshtawy RI, El-Sisy GA, El-Nattat WS. 2016. Effects of pomegranate juice in Tris-based extender on cattle semen quality after chilling and Cryopreservation. Asian Pac J Reprod; 5(4): 335-339

Guo C., Wei J., Yang J., Xu J., Pang W., Jiang Y. 2008. Pomegranate juice is potentially better than apple juice in improving antioxidant function in elderly subjects. Nutr. Res., 28: 72-77.

Hmid I, Elothmani D, Hanine H, Oukabli A, Mehinagic E. 2013. Comparative study of phenolic compounds and their antioxidant attributes of eighteen pomegranate (Punica granatum L.) cultivars grown in Morocco. Arab J Chem; Inpress

Iaffaldano N, Rosato MP, Paventi G, Pizzuto R, Gambacorta M, Manchisi A. 2010. The irradiation of rabbit sperm cells with $\mathrm{He}-\mathrm{Ne}$ laser prevents there in vitro liquid storage dependent damage. Anim Reprod Sci; 119:123-129.

Ismail H. Chan K. Mariod A. and Ismail M. 2010. "Phenolic Content and Antioxidant Activity of Cantaloupe (Cucu- mis melo) Methanolic Extracts," Food Chemistry, 119 (2): 643647.

Johinke D, de Graaf SP, Bathgate R. 2014. Quercetin reduces the in vitro production of $\mathrm{H}_{2} \mathrm{O}_{2}$ during chilled storage of rabbit spermatozoa. Anim Reprod Sci; 151: 208219.

Khalafalla, M. M., Abdellatef, E., Dafalla, H. M., Nassrallah, A. A., Aboul-Enein, K. M., Lightfoot, D. A., et al. 2010. Active principle from Moringa oleifera Lam leaves effective against two leukemias and a hepatocarcinoma. African Journal of Biotechnology, 9: 8467-8471

Kim S, Lee YJ, Kim YJ. 2011. Changes in sperm membrane and ROS following cryopreservation of liquid boar semen stored at $15^{\circ} \mathrm{C}$. Anim Reprod Sci; $124 ; 118-124$.

Moce' E, Vicente JS. 2009. Rabbit sperm cryopreservation: a review. Anim Reprod Sci; $110 ; 1-24$.

Moretti E., Mazzia L., Terzuolia G., Bonechic C., Iacoponia F., Martinic S., Rossic C., Collodela G. 2012. Effect of quercetin, rutin, 
naringenin and epicatechin on lipid peroxidation induced in human sperm. Reproductive Toxicology; 34: 651-657

Mourvaki, E., Cardinali, R., Dal Bosco, A., Castellini, C., 2010. In vitro antioxidant activity of the prostatic secretory granules in rabbit semen after exposure to organic peroxides. Reprod. Biol. Endocrinol. 8, 16.

Moyo B., Oyedemi S., Masika P.J., Muchenje V. 2012. Polyphenolic content and antioxidant properties of Moringa oleifera leaf extracts and enzymatic activity of liver from goats supplemented with Moringa oleifera leaves/sunflower seed cake. Meat Science, 9:441-447

Nishikimi, M., Roa, N.A., Yogi, K. 1972. Biochem. Bioph. Res. Common., 46, $849-$ 854

Ohkawa, H., Ohishi, N. and Yagi, K. 1979. Assay for lipid peroxides in animal tissues by thiobarbituric acid reaction. Anal. Biochem, 95: 351-358.

Panichayupakaranant, P., Tewtrakul, S., Yuenyongsawad, S. 2010. Antibacterial, anti-inflammatory and anti-allergic activities of standardised pomegranate rind extract. Food Chemistry, 123(2): 400-403.

Qu, W. J., Breksa, A. P. \& Ma, H. 2012. Quantitative determination of major polyphenol constituents in pomegranate products. Food Chemistry, 132, 1585-1591.

Reddy M, Gupta S, Jacob M, Khan S, Ferreira D. 2007. Antioxidant, antimalarial and antimicrobial activities of tannin-rich fractions, ellagitannins and phenolic acids from Punica granatum L. Planta Med; 73:461-467.

Roopalatha, UC. and Nair, VM. 2013. Phytochemical analysis of successive reextracts of the leaves of moringa oleifera lam. International Journal of Pharmacy and Pharmaceutical Sciences, 5: 629-634.

Rosato MP, Iaffaldano N. 2011. Effect of chilling temperature on the long-term survival of rabbit spermatozoa held either in a Trisbased or a jellified extender. Reprod Domest Anim; 46: 301-308.

SAS. 2008. Statistical analysis system: User's guide v. 9.2, Inst. Inc., Cary N.C., USA.

Türk G., Sönmez M., Aydin M., Yüce A., Gür S., Yu"ksel M., Aksu EH., Aksoy H., 2008. Effects of pomegranate juice consumption on sperm quality, spermatogenic cell density, antioxidant activity and testosterone level in male rats. Clinical Nutrition, 27: 289-296.

Yousef, M. I., Abdallah, G. A. and Kamel, K. I. 2003. Effect of ascorbic acid and Vitamin E supplementation on semen quality and biochemical parameters of male rabbits. Anim Reprod Sci; 76: 99-111.

Yüce A, Aksakal M 2007. Effect of pomegranate juice on antioxidant activity in liver and testis tissues of rats (Article in Turkish). Firat University Journal of Health Sciences, 21: 253-256. 